\title{
NEC3 and NEC4 Compared
}


Downloaded by [] on [26/04/23]. Copyright $\odot$ ICE Publishing, all rights reserved. 


\section{NEC3 and NEC4 Compared}

\section{Robert Alan Gerrard} BSc (Hons), FRICS, FCInstCES 
Published by ICE Publishing, One Great George Street, Westminster, London SW1P 3AA.

Full details of ICE Publishing representatives and distributors can be found at: www.icebookshop.com/bookshop_contact.asp

Other titles by ICE Publishing:

- NEC4 Practical Solutions

R. Gerrard and S. Kings. ISBN: 978-0-7277-6199-6

- Managing Reality, A practical guide to applying NEC4, Third Edition. 5-volume set.

B. Mitchell and B. Trebes. ISBN 978-0-7277-6195-8

- NEC4: The Role of the Project Manager

B. Mitchell and B. Trebes. ISBN: 978-0-7277-6353-2

www.icebookshop.com

A catalogue record for this book is available from the British Library

ISBN 978-0-7277-6201-6

(C) Thomas Telford Limited 2017

First published 2017

Reprinted 2018, 2019

Reprinted with amendments July 2019

ICE Publishing is a division of Thomas Telford Ltd, a wholly-owned subsidiary of the Institution of Civil Engineers (ICE).

All rights, including translation, reserved. Except as permitted by the Copyright, Designs and Patents Act 1988, no part of this publication may be reproduced, stored in a retrieval system or transmitted in any form or by any means, electronic, mechanical, photocopying or otherwise, without the prior written permission of the Publisher, ICE Publishing, One Great George Street, Westminster, London SW1P 3AA.

This book is published on the understanding that the author is solely responsible for the statements made and opinions expressed in it and that its publication does not necessarily imply that such statements and/or opinions are or reflect the views or opinions of the publishers. While every effort has been made to ensure that the statements made and the opinions expressed in this publication provide a safe and accurate guide, no liability or responsibility can be accepted in this respect by the author or publishers.

While every reasonable effort has been undertaken by the author and the publisher to acknowledge copyright on material reproduced, if there has been an oversight please contact the publisher and we will endeavour to correct this upon a reprint.

Commissioning Editor: Michael Fenton

Production Editor: Madhubanti Bhattacharyya

Market Development Executive: Elizabeth Hobson

Typeset by Manila Typesetting Company

Printed and bound in Great Britain by Bell and Bain, Glasgow 


\section{Contents}

Amendments January 2019

\begin{tabular}{|c|c|}
\hline VERS & \\
\hline Sched & le of Options \\
\hline Core $\mathrm{C}$ & auses \\
\hline 1 & General \\
\hline 2 & The Contractor's main responsibilities \\
\hline 3 & Time \\
\hline 4 & Quality management \\
\hline 5 & Payment \\
\hline 6 & Compensation events \\
\hline 7 & Title \\
\hline 8 & Liabilities and insurance \\
\hline 9 & Termination \\
\hline
\end{tabular}

\section{Main Option Clauses}

A Priced contract with activity schedule

B Priced contract with bill of quantities

2

C Target contract with activity schedule

D Target contract with bill of quantities

$6 \quad 7$

E Cost reimbursable contract

$6 \quad 7$

F Management contract

$\begin{array}{rr}6 & 7 \\ 18 & 19\end{array}$

$24 \quad 25$

$30 \quad 31$

$36 \quad 37$

$42 \quad 43$

$56 \quad 57$

$58 \quad 59$

$64 \quad 65$

Resolving and Avoiding Disputes 106 


\section{Amendments January 2019}

The NEC4 suite of contracts was published in June 2017. Following publication there has been discussion of and feedback from users and industry experts on the new features, forms and changes which were introduced. The feedback has been extremely positive overall and has provided many constructive suggestions as to how the contracts could be further enhanced.

To build on the constructive feedback and further improve the contracts the NEC has published a set of amendments in January 2019, which can be accessed here: https://www. neccontract.com/About-NEC/News-Media/NEC4-Amendments. Users should consider reflecting these changes in their upcoming tenders or existing contracts as amendments.

In July 2019 this guide was updated to reflect the January 2019 amendments. On each page where the NEC4 contract was amended in 2019 there is now a footnote alerting readers to the January 2019 amendments: "This page has been amended in 2019". 